\title{
Ownership Structure, Technological Endowment and Competitive Advantage: Do Democracy and Business Fit?
}

\author{
SEBASTIÁN BRUQUE, JOSÉ MOYANO, ALFONSO VARGAS \& \\ M. JESÚS HERNÁNDEZ
}

\begin{abstract}
The current study provides a model that aims to explain the origin of the competitive advantage of organizations in terms of the ownership structure. We have also studied the interactions between IT use and ownership structure. To reach these objectives, we have classified the organizations in two groups using the cooperative character criterion. The results show that cooperative firms achieve a superior competitive advantage regardless of the amount of IT that the firms use. The study is focused on the Spanish Pharmaceutical Distribution Industry.
\end{abstract}

\section{Introduction}

In the field of Business Management and Administration, one of the most traditional research topics is the analysis of the origins of competitive advantage. Ricardo ${ }^{1}$ describes the procedure through which firms obtain superior economic income thanks to the fact that control the most valuable resources. Later, other classic authors such as Selznick, ${ }^{2}$ Penrose, ${ }^{3}$ Chandler, ${ }^{4}$ and Andrews ${ }^{5}$ also attempt to find logical explanations for the origin of competitive advantage.

During the last two decades important progress has been made in the theoretical articulation of the underlying causes of organizational success. Porter ${ }^{6}$ establishes that the causes of business success depend, basically, on the structure of industrial sectors and the competitive forces affecting them. Wernerfelt ${ }^{7}$ and Barney $^{8}$ stipulate that the original cause of competitive advantage stems from company ownership of specific resources, which are both capable of generating value and scarce or difficult to imitate or to substitute.

As part of the research of causal relationships which explain how superior organizational results have been achieved, a line of research has been developed during the last few decades that links the financial structure to the gaining of better results. ${ }^{9}$ These studies, which have reached several conclusions, analyze the links that may exist between the concentration of capital in hands of a reduced number of owners (control situation)

Sebastián Bruque and José Moyano are at the University of Jaén, Department of Business Administration, Accounting and Sociology, Jaen, Spain (Tel: + 34953026 571; Fax: + 34953026 508; Email: sbruque@ujaen.es and jmoyano@, ujaen.es). M. Jesús Hernández is in the same department at the Campus de las Lagunillas, Edf. D-3, 23009 Jaén, Spain (Tel: + 34953012 205; Fax: + 34953012 222; Email: mjhernan@ujaen.es). Alfonso Vargas is at the University of Huelva, Department of Management and Marketing, Plaza de la Merced, 11, 21002 Huelva, Spain (Tel: + 34959017 845; Fax: + 34959017 839; Email: vargas@uhu.es). 


\section{S. Bruque et al.}

and the obtaining of better business results. ${ }^{10}$ On other occasions the influence of certain characteristics of majority members on business results is studied, such as the public or private link. $^{11}$

However, literature on competitive advantage and ownership structure has paid little attention to the influence that the democratic ownership and control can have on competitive advantage. More specifically, there are very few works that analyze, from an empirical angle, the differences in results achieved by cooperative firms as opposed to noncooperative firms that work in one given industry. ${ }^{12}$ Based on theoretical developments, the advantages to be gained by the democratic participation inherent in the cooperative formula have been pointed out on several occasions, ${ }^{13}$ but there is very little evidence that supports this hypothesis and there are no precedents that explain the role that can be played by technical and human elements when they interact with an organization and cooperative management with the aim to obtain better competitive results.

In this paper we aim to take the first step towards filling the gap in research we have just mentioned by studying the interrelations existing between ownership structure and competitive advantage, without ignoring the influence that technology may have on the relationship.

\section{Theoretical Background}

Ownership structure defines the institutional basis for power relationships between individuals within the organization and dealings with other organizations. ${ }^{14}$ The ownership rights system included in organizational structure plays an important role given that it generates collective behaviour and drives individuals to control and promote their own interests. In this sense, the structure of ownership rights can be considered to be a set of specific, observable and stable instructions to generate, organize and determine collective action. $^{15}$

Based on ownership structure, firms can be classified as cooperative companies and capitalist companies. ${ }^{16}$ In the capitalist company, the underlying motivation is the possibility for owners to obtain benefits on the investment made in the business. However, in a cooperative company, the main incentive is the satisfaction of a common socioeconomic necessity.

The cooperative firm is a particular type of company in which the active and effective participation in the production and/or commercialization process is what legitimizes the capacity to take decisions democratically amongst its members on the company's objectives. ${ }^{17}$ The only way to participate in this process is if the member is at the same time a supplier to the company or a client. By supplying goods, work or as a consumer one participates in the activity, and through participation the social objective of the cooperative company is achieved. Through participation expectations are fulfilled and the need is satisfied. ${ }^{18}$ On the other hand, in the capitalist company the role of supplier, entrepreneur and client are normally played by different individuals.

The double role of member-client, or member-supplier, which arises in cooperative companies, could imply an increase in commitment by the people involved in building the company. The research done by Locke and Schweiger ${ }^{19}$ and Schweiger and Leana ${ }^{20}$ demonstrates the existence of a positive relationship of participation and the level of satisfaction and commitment on the part of the members.

A key difference between cooperative firms and capitalist firms is that, in cooperative firms, the organizational power is related to the individual but not to the capital. Cooperative firms also have a distinctive culture, based on certain principles and values (such as democracy and equity), which are shared and assumed freely by all their 
members. The distinctive culture, together with a high level of commitment on the part of members, suggests the idea that cooperative firms could be closer than other firms to some excellence keys observed in empirical research. ${ }^{21}$ It could be possible therefore to identify cooperative members as a part of the human capital of the cooperative firm. A higher commitment from members and workers to the firm may improve the quality of the human capital, ${ }^{22}$ an effect that may constitute the basis for the construction of solid competitive advantages. ${ }^{23}$ This reasoning allows us to draw up the following hypothesis:

Hypothesis 1: Cooperative firms achieve a higher level of competitive advantage than noncooperative firms.

The use of IT (specially those related to computing, communications and robotics) can give the organization using it a competitive advantage over its rivals. ${ }^{24}$ In the particular case of cooperative firms, the positive effect generated by IT could be added to the effect emerging from the application of cooperative principles.

It has been pointed out in previous studies that the existing link between IT and competitive advantage would be regulated by certain complementary elements. ${ }^{25}$ Powell and Dent-Micallef ${ }^{26}$ state that the competitive effect of technology is higher when other non-tangible elements merge, elements such as a clear support on the part of the upper management for technologic updating, low conflict levels, and high technical and training qualities on the part of the staff. This idea has in fact been corroborated in subsequent studies, ${ }^{27}$ in which other resources are also mentioned, such as organizational flexibility or the degree of interdepartmental equipment use. By virtue of what has been said before, a positive complementary effect may also exist between the use of IT and the application of cooperative principles, specially those related to the commitment and participation of members in the business activity (principle of democratic member control and principle of member economic participation). In this way, cooperative firms could strengthen their position in the market by means of the implantation and use of IT. The link between both circumstances, cooperative formula and technological development, may produce a synergic effect that may affect the competitive advantage in a positive way. This statement is presented in Hypothesis 2.

Hypothesis 2: The competitive advantage of cooperative firms as opposed to non-cooperative firms is positively related with the degree of usage of IT.

\section{The Pharmaceutical Distribution Sector in Spain}

The pharmaceutical macro sector in Spain is structured in three clearly differentiated activity areas, in terms of its characteristics and economic structure. The most important area, in terms of activity and employment is the investigation, development and production of pharmaceutical specialities, made up of 378 laboratories, employing approximately 38400 people in $1998 .^{28}$ The second sector is made up of the organizations in charge distributing the products from the production areas to retailers-pharmacies. This area, named 'pharmaceutical distribution' or 'wholesale pharmaceutical distribution' is made up by 77 business groups that in 1998 had an overall turnover of more than $€ 6000$ million. $^{29}$

The third sub-sector of the pharmaceutical industry is retailer distribution, made up of 19222 pharmacies, ${ }^{30}$ and responsible for the functions related to medicines and pharmaceutical speciality delivery to the final user. In Table 1 we have a summary of the main figures of the pharmaceutical macro sector. 
Table 1. Main figures of the Spanish pharmaceutical macro-sector

\begin{tabular}{lcrrrr}
\hline & $\mathbf{1 9 9 4}$ & $\mathbf{1 9 9 5}$ & $\mathbf{1 9 9 6}$ & $\mathbf{1 9 9 7}$ & $\mathbf{1 9 9 8}$ \\
\hline Production ( $€$ million) & 4398.81 & 4926.50 & 5415.94 & 5897.21 & 6392.85 \\
Exportation ( $€$ million) & - & 912.08 & 1058.69 & 1350.68 & 893.79 \\
Importation ( $€$ million) & - & 171.36 & 1895.93 & 237.06 & 1839.67 \\
National Health Service pharmaceutical speciality & & & & & \\
$\quad$ consumption through pharmacies $(\boldsymbol{C}$ million) & 3816.47 & 4332.99 & 4813.22 & 5062.11 & 5566.95 \\
Number of pharmacies & 18721 & 18745 & 18909 & 19080 & 19222 \\
Number of active laboratories & - & 340 & 337 & 334 & 378 \\
Employment in active firms (except distribution) & - & 35000 & 34900 & 34800 & 38400 \\
\hline
\end{tabular}

Source: Own design based on ESADE, 'Flashes sectoriales, industria farmacéutica', available at http://www.guiame.net/ flash/farma.html, 12nd July 2000; FARMAINDUSTRIA, 'La industria farmacéutica en cifras', 1999, Madrid, Farmaindustria.

Pharmaceutical distribution in Spain has consolidated as a branch of a very dynamic activity. The use of pharmaceutical products, only in the National Health Service, was valued at more than $€ 5500$ million in 1999, which gave rise to the direct employment of 8500 workers in this sector, only taking into account jobs directly related to distribution firms. Distribution firms must front a demand made up of the pharmacies located all over the country, besides hospitals integrated in the National Health Net and in the Private Health Service. The main objective of this organization is to serve as a link between the pharmaceutical specialities production firms and the retailer distribution firms. The pharmaceutical distribution activity is regulated by the administration by means of certain laws.

According to the census done by the management, which groups together firms of this sector-FEDIFAR - in 1998 there were in Spain 99 different companies dedicated to wholesale pharmaceutical distribution, having 192 territorial distribution warehouses at their disposal. Because of the control relations between different entities, it is calculated that only 77 out of 99 existing societies are constituted in self-decision centres. ${ }^{31}$ These organizations are distributed in two subgroups, differentiated according to their ownership structure, cooperative firms and the rest, which are made up of capitalist firms.

According to the census done by ACOFARMA, an entity grouping distribution cooperative firms, 31 cooperative firms existed in 2000. These firms appeared, in most cases, as a consequence of the formation of groups of pharmacists, taking place in the period 1940-1950, with the intention of creating their own wholesale distribution firm. ${ }^{32}$ This system should be able to respond to the problems of: (1) increasing the supply of pharmaceutical specialities; (2) increasing the complexity in manipulation, classification and delivery of medicines and (3) creation of their own corporative power as opposed to those capitalist firms specialized in pharmaceutical distribution.

\section{Method}

\section{Data}

In order to test the above hypotheses we have used as the sector of activity the one made up of pharmaceutical distribution firms. The reasons why we chose this particular sector were the following: (1) ownership structure is a distinctive feature of firms participating in this sector, and (2) the proficient technological development these firms have reached. In fact, their activity consists in managing the complex information flows, which are 
necessary for the acquisition, classification, storage and delivery of more than 20000 references of highly specialized products. ${ }^{33}$

The geographical sphere that we have chosen corresponds to an area with similar patterns relating to the supply and demand of pharmaceutical products, that is, Southern and Central Spain, where we can find 8834000 inhabitants $22 \%$ of Spanish total population). The usage of pharmaceutical products in 1998 in this area was valued in $€ 1384$ million. This amount is equivalent to $22.4 \%$ of the Spanish absolute figures.

To carry out this work we have used information coming from two sources: (1) a personal interview with several members of pharmaceutical distribution firms and (2) a postal survey addressed to clients of these firms.

With respect to the first source, we visited during at least one working day every pharmaceutical distribution company operating in the geographical sphere previously mentioned (16 firms, nine cooperative firms and seven non-cooperative firms), holding personal interviews with members of different organizational levels. Therefore this work comprises the whole population in the aforementioned area. The period of information gathering ran from December 1999 to October 2000. For each company, we held interviews with at least two members of the organization: one senior executive and the IT/information systems director. When the company did not have an IT/IS director, two IT workers were interviewed. In total we carried out 36 interviews. The purpose of this methodology was as follows: by obtaining at least two independent responses from each firm we mitigated the effects of single-response bias, and we could measure the inter-rater reliability of the scales.

The questions used in the questionnaire are shown in Appendix 1 and were chosen according to the questionnaire of IT resources in Powell and Dent-Micallef ${ }^{34}$ after adaptation to the technologies used in the Spanish Pharmaceutical Distribution Industry. The questionnaire scales were pretested using three respondents (two IT managers and one industry expert). As an internal reliability measurement ${ }^{35}$ we calculated the average correlation degree between the answers to a concrete item given by the different participants, with a value of 0.48 (Spearman correlation coefficient). Whenever possible, Cronbach's alpha was computed as a measure of scale reliabilities. ${ }^{36}$ Although this index has no minimum, some authors suggest 0.35 as the limit for ensuring an acceptable coherence for each dimension. ${ }^{37}$ In other cases the figure 0.70 is mentioned. ${ }^{38}$ In our study we obtained an average value of 0.80 , whereby expectations regarding the reliability of the scales used in the interviews were amply fulfilled.

The second source of information used was a postal survey sent to pharmaceutical clients that operate in the geographical area mentioned. The population is made up of 3803 pharmacies. ${ }^{39}$ Based on a disproportionate stratified random sample, a total of 1060 questionnaires were sent out. The population was stratified according to the geographical area (province) criterion. This criterion was chosen tanking into account that most of the organizations analyzed operate in only a part of the territory, which in turn means that the client will only be familiar with a limited number of organizations. Following the guidelines of Sekaran, ${ }^{40}$ we used a disproportionate method to assure that every firm has a minimum number of client valuations so we sent the same number of questionnaires to each province. A total of 231 valid questionnaires were returned (see Appendix 2), giving a final response index of $21.86 \%$. This figure is comparable to those obtained by previous studies in the field of business analysis. ${ }^{41}$ The final response rate was obtained after having adopted the means necessary to reduce the error produced by the no response rate. These means could be summed up as: (1) use of at least two telephone calls as a form of follow-up and reminder and (2) simplification of the questionnaire and answers during the planning stage. 


\section{S. Bruque et al.}

The questionnaire sent to the pharmaceutical clients was made up of 16 questions based on Likert type scales. Each participant was asked to value, on a 1-10 scale, the quality of the service that, in his/her opinion, the respective distribution companies had provided during the previous two years.

\section{Variables}

Ownership structure. This variable was defined as a dichotomous variable which shows if the company is a cooperative company (value 1) or not (value 0).

Competitive advantage index. We have not used profitability indexes (e.g. ROI) to measure competitive advantage because profitability measures lose a large part of their efficacy in our study. The reason is the important role that cooperative firms have acquired in this industry. Cooperative firms control more than $70 \%$ of the market in the Spanish Pharmaceutical Distribution Industry. Organizations with this form of legal status tend to engage in anticipated distribution of profits such that measures based on profitability can be distorted. ${ }^{42}$

According to Barney's definition, ${ }^{43}$ a company has competitive advantage when it carries out activities that increase its efficacy or efficiency in comparison with rival organizations. Based on this definition, an external index to value the competitive advantage of each organization has been drawn up. In order to do this we have used two measures, one of an objective nature based on the market share, and the second based on the personal valuation made by clients.

The first index shows the average variation of the market share during the period 1994-1998. The period of reference was 5 years in order to reduce the effects of time factors that could have had a circumstantial influence on competitive advantage. The use of this index is justified if we take into account that: (1) it is independent of the accounting policy applied by each company given that it depends only on the total sales of the company as opposed to the total sales of the sector as a whole, (2) it eliminates the influence of the individual size of each company on competitive advantage, (3) it eliminates the impact that inter-annual sales growth in the sector as a whole can have on individual business figures and, finally, (4) similar indexes have already been used to measure competitive advantage. ${ }^{44}$

The mathematical expression proposed shows that the average variation of market share is the following:

$C_{i 94 / 98}=\left[\frac{\sum_{t=95}^{t=98}\left(\frac{I_{i t} / I T_{t}}{I_{i t-1} / I T_{t-1}}\right)}{4}\right] \cdot 100$

where $C_{i 94 / 98}$ is the average variation of the market share for the company $i$ during the period 1994-1998, $I_{i t}$ is the operating income for the company $i$ during the period $t, I_{i t-1}$ is the operating income for the company $i$ during the period $t-1, I T_{t}$ is the operating income for the national market during the period $t$ and $I T_{t-1}$ is the operating income for the national market during the period $t-1$.

Based on the information obtained from the questionnaire sent to pharmaceutical 
clients, the second index shows their average valuation given to distribution companies with which they operate. In the questionnaire the client was asked to evaluate each distribution company in a scale of 1 to 10 , according to the quality of global service.

Both of the indexes mentioned have certain drawbacks in providing a reliable measurement of competitive advantage. The first index could be criticized in so far as sales figures can not depict competitive advantage due to the effect of the acquisition, fusion or organizational restructuring processes suffered by companies belonging to the sector under analysis. The second index could be an imprecise indicator of competitive advantage given the discontinuous nature of the market. This situation arises due to the fact that the organizations analyzed usually operate in a limited geographical area, which in turn means that the client will only know a limited number of organizations. Consequently, an organization operating with few competitors could obtain a considerably better valuation than others operating in more congested areas.

To overcome the difficulties mentioned we propose using a joint index, thereby reducing the multidimensional nature of competitive reality in the sector to just one expression. However, if we combine these two indexes, the problem of the difference in nature of both of them arises. On one hand, the variation of the market share represents a percentage variation, while the clients' valuation is taken from a 1-10 Likert scale. We have tried to solve this problem by standardizing each of the indexes. Once they are standardized, we propose taking the sum of both indicators as a combined ratio. In this way, we aim to keep the positive aspects of the previous indexes, while reducing their possible defects.

$I_{c i}=C_{i 94 / 98}^{\prime}+V_{i}^{\prime}$

where $I_{c i}$ is the competitive advantage index, $C_{i 94 / 98}^{\prime}$ is the increase in the market share during the period 1994-1998 (standardized values) and $V_{i}^{\prime}$ is the average valuation of pharmaceutical clients (standardized values).

Technological index. A technological index has been defined to show robotic, computer and telecommunications technology usage. During the preliminary study a total of 17 types of technology used in the pharmaceutical distribution sector were identified (robotic, telecommunications and computing technologies). This technology was valued by including $0-5$ Likert type scales in the questionnaire sent to the members of the organizations participating in the survey. Value 0 indicated that the organization was not interested in the use of the technology, value 1 indicated that the company was interested in the use of the technology, but had not yet begun to use it, and value 5 indicated that technology was intensely used. The technological index was drawn up based on the arithmetic average of the marks obtained in the 17 technological items. ${ }^{45}$

\section{Control variables}

In order to test the hypotheses we have had to control other variables, that like the independent variables, can have an influence on competitive advantage. Two types of control variables have been introduced. On the one hand, specific company characteristics that may affect competitive results have been introduced. On the other hand, variables that are representative of the market in which these companies work are included.

Size. Organizational size is a fundamental control variable in numerous studies made in the field of organizational analysis. ${ }^{46}$ As in the study made by Powell and Dent- 


\section{S. Bruque et al.}

Micallef ${ }^{47}$ it has been calculated as the average number of employees in the company from 1994 to 1998.

Age. The hypothesis of age influence on organizational structure is put forward in organizational theory. More specifically, it is considered that the older the organization, the more formalized will its behaviour be and the more developed its activity and hierarchy. ${ }^{48}$ For this reason the influence that age can have on the organization's competitive advantage has been controlled ${ }^{49}$ and the period covered has been calculated from the beginnings of the organization up to 1999.

Efforts made in commercial promotion. In several studies, the efforts made in commercial promotion have been considered control variables in shape of publicity costs. ${ }^{50}$ We have controlled the effect of the efforts made in commercial promotion based on a perceptual measurement of the efficacy of the sales force. Publicity costs in the pharmaceutical distribution sector are practically nil since business is done in a business to business environment in which commercial promotion is carried out through the sales force. ${ }^{51}$ Given that there are no direct measurements of the cost of sales force, we have used a perceptual variable ${ }^{52}$ by including a Likert $1-5$ type question in the survey made on company managers. In answer to this question, the people surveyed gave their opinion regarding the level of sales force efficacy in comparison with rival companies.

Geographical diversification. One of the variables which allows us to explain the competitive advantage gained by an organization is the diversification in geographical markets variable. ${ }^{53}$ In the industry we are analyzing this variable is of particular relevance given the localized geographical situation of competitors. It was calculated based on the valuation made by company directors on strategic orientation towards territorial expansion using a Liker $1-5$ type scale.

Variation in demand. The effect of variations in demand on competitive advantage has been controlled in several previous studies. ${ }^{54}$ In this case, the fragmented nature of the market in which the companies analyzed work could also give rise to an overvaluation in one of the indexes used to show competitive advantage. More specifically, an overvaluation would appear in the $C_{i 94 / 98}$ index for those entities which obtain a more favourable portion of the market due to the fact that they operate in an area where pharmaceutical consumer growth is over and above the national average. To control this effect, we have included this variable which was calculated based on the relationship existing between the average pharmaceutical consumer growth in the province/s where each organization operates for the period 1994-1998 and the average pharmaceutical consumer growth for Spain during the same period.

$$
F_{c i}=\left[\frac{\left(\left\{\sum_{t=95}^{t=98} C_{i t} / C_{i t-1}\right\} / 4\right)-1}{\left(\left\{\sum_{t=95}^{t=98} C \mathcal{T}_{t} / C \mathcal{T}_{t-1}\right\} / 4\right)-1}\right]
$$

where $F_{c i}$ is the index of demand variation, $C_{i t}$ is the consumption of pharmaceutical products in the area where company $i$ during the period $t, C_{i t-1}$ is consumption of 
pharmaceutical products in the area where company $i$ during the period $t-1, C T_{t}$ is consumption of pharmaceutical products for the national total during the period $t$, and $C T_{t-1}$ is consumption of pharmaceutical products for the national total during the period $t-1$.

\section{Analysis}

Table 2 shows the averages, standard deviations and correlations for the variables used in this article.

In order to reveal the determinants of competitive advantage, we have designed various multiple regression models (Table 3). As in other papers, ${ }^{55}$ we have used this methodology to try to discover the origin of competitive advantage. To use this methodology, the hypothesis of normality in the distribution of residuals in the models built must be fulfilled. To this end we have carried out the Kolmogorov-Smirnov and ShapiroWilk normality tests.

We have also analyzed the existence of colineality between the independent variables used in the regression models. ${ }^{56}$ In order to do this we have calculated the tolerance of each variable as well as their respective inflation factors and we have obtained results that indicated no problems of multicollinearity.

Table 2. Descriptive and correlation statistics

\begin{tabular}{|c|c|c|c|c|c|c|c|c|c|}
\hline Variables & Mean & SD & 1 & 2 & 3 & 4 & 5 & 6 & 7 \\
\hline 1. Ownership structure & 0.62 & 0.50 & & & & & & & \\
\hline 2. Technological index & 2.46 & 0.90 & $0.78^{* * *}$ & & & & & & \\
\hline 3. Competitive advantage index & 0.01 & 1.91 & $0.61^{*}$ & 0.40 & & & & & \\
\hline 4. Size & 136.1 & 171.9 & $0.72^{* * *}$ & $0.79 * *$ & 0.45 & & & & \\
\hline 5. Age & 42.37 & 17.98 & $0.56^{* *}$ & 0.50 & $0.66^{* *}$ & $0.76^{* *}$ & & & \\
\hline 6. Efforts in comercial promotion & 3.01 & 1.08 & -0.11 & 0.21 & -0.14 & 0.24 & 0.20 & & \\
\hline 7. Geographical diversification & 2.56 & 1.50 & 0.08 & 0.38 & -0.01 & 0.37 & 0.21 & $0.88 * *$ & \\
\hline 8. Market share variation & 0.84 & 0.09 & -0.14 & 0.07 & -0.32 & 0.15 & -0.23 & 0.06 & 0.21 \\
\hline
\end{tabular}

*The correlation is significant at 0.05 level.

** The correlation is significant at 0.01 level.

Table 3. Multiple regression models of ownership structure and IT. Influence on competitive advantage

\begin{tabular}{lcccc}
\hline Variables & Model 1 & Model 2 & Model 3 & Model 4 \\
\hline Ownership structure & $0.58^{*}$ & $0.58^{*}$ & $0.58^{*}$ & $0.58^{*}$ \\
Technological Index & & -0.38 & & -0.38 \\
Ownership structure $\times$ technological index & & & -0.35 & -0.35 \\
Size & 0.01 & 0.01 & 0.01 & 0.01 \\
Age & 0.14 & 0.14 & 0.14 & 0.14 \\
Effort in commercial promotion & -0.14 & -0.14 & -0.14 & -0.14 \\
Geographical diversification & 0.01 & 0.01 & 0.01 & 0.01 \\
Variation in demand & -0.19 & -0.19 & -0.19 & -0.19 \\
Corrected $R^{2}$ & & & & 0.293 \\
$F$ & 0.293 & 0.293 & $7.21 *$ & $7.21^{*}$ \\
\hline
\end{tabular}

$* p<0.05 ; * * p<0.01$. 


\section{S. Bruque et al.}

\section{Results}

In Table 3 a series of regression models has been built to test the influence exerted by the explicative variables on competitive advantage. Model 1 shows the impact of the ownership structure without considering any IT interaction. Meanwhile model 2 through model 4 take account of the IT and ownership structure variables at the same time. We used models 1 and 4 to test Hypothesis 1 and models 2-4 to test Hypothesis 2. In models 3 and 4 we have introduced the cross-effect of IT and ownership structure to test for multiplicative effects between IT utilization and cooperative ownership structure. The results presented in models 1 and 4 are consistent with Hypothesis 1. On the other hand, the results presented in models 2, 3 and 4 do not support Hypothesis 2.

From the regression models we can deduce that the only variable that has any significant influence on competitive advantage is the company's ownership structure. We can see how the cooperative form is associated with higher levels of competitive advantage.

Finally, we must point out that organizational and market control variables do not have any significant influence on the level of competitive advantage in companies belonging to the pharmaceutical distribution industry.

\section{Conclusions}

The results of this paper suggest that a new dimension exists in the study of competitive advantage in companies belonging to a given sector. More specifically, the findings obtained allow us to establish a relationship between democratic ownership and competitive advantage.

The underlying mechanisms that may explain the higher competitive performance of the cooperative may be related to the degree of commitment existing between the firm company and the members, and to the specific cultural characteristics of cooperatives. This explanation coincides with the arguments put forward by Vargas and Rodrigo ${ }^{57}$ with reference to the keys to business excellence in a cooperative firm.

The results previously mentioned can also be reasoned in line with the resource based view (RBV) of the firm. The commitment relationship between company and members and the cultural values inherent to cooperative firms may constitute a valuable resource, given the fact that results in this study confirm that cooperative firms achieve a superior competitive advantage. We can also consider that the special member-client commitment relationship in cooperative firms is a rare resource taking into account that it is not available to every firm in the industry (it is not available to non-cooperative firms). What is more, this resource may be the key to achieving a sustainable competitive advantage if we consider that, as an intangible element, its transmission or substitution amongst other companies would be difficult. ${ }^{58}$ In this way, the bases established in the VRIO ${ }^{59}$ (value, rarity, inimitability, organizational embedded) model, by which a business element capable of generating competitive advantages must generate value, be scarce, be difficult to imitate or substitute and be interrelated to other resources of the organization may be fulfilled.

Within our conclusions, the results obtained on the role played by IT in competitive advantage are worth a special mention. We have not been able to detect a statistically significant relationship between the use of technology, considered in isolation, and improved competitive advantage. Based on our results, technology would, in the strictest sense, be a necessary instrument, but not sufficient to achieve competitive advantage. This statement is in line with the strategic necessity hypothesis ${ }^{60}$ and with the concept of technological paradox ${ }^{61}$, which hold that technology, particularly IT, would not automatically result in improved performance in the companies where it is used. 
Nor do the results support the existence of a complementary, synergic relationship, between a greater use of IT, the cooperative character of the firm and a higher competitive advantage (Hypothesis 2). According to the RBV, the intensive use of IT in cooperative, democratically managed organizations may be a resource difficult to imitate and duplicate. However, our results do not indicate that this is a valuable resource given the fact that it is not related to a higher competitive performance. In short, although the literature has found several human or managerial resources with a positive, synergic effect when used jointly with IT, this is not the case of the cooperative ownership structure.

The results of this paper constitute an initial approach to understanding the relationship that exists between democratic ownership structure and competitive advantage. The validity and the generalization of the conclusions mentioned are at the mercy of future research done in other industries or sectors that ratifies or refutes them. Likewise, we must be aware of this paper's limitations. More specifically, we have centred our research on one specific type of cooperative company where members are clients, and we have not contemplated the alternative type of cooperative in which the members are suppliers who provide the company with goods or work. On the other hand, and in the case of capitalist companies, the influence exerted by ownership structure and company control on competitive advantage is not analyzed.

Given the limitations mentioned, there are several lines of research which could be undertaken as a follow on to this paper: (a) the study of the relationship which exists between ownership structure and competitive advantage when the role of member is linked to the role of company supplier; (b) the examination of the links existing between ownership structure and the composition of the company's management team and its influence on competitive advantage; (c) research into the relationships that can be maintained by the ownership structure and the characteristics of the industry at any given time and its influence on the ability to achieve sustainable competitive advantage.

\section{Notes and References}

1. D. Ricardo, Principles of Political Economy and Taxation (London, Murray, 1817).

2. P. Selznick, Leadership in Administration: A Sociological Interpretation (New York, Harper and Row, 1957).

3. E.G. Penrose, The Theory of the Growth of the Firm (New York, Wiley, 1959).

4. A.D. Chandler, Strategy and Structure: Chapters in the Story of the History of the American Industrial Enterprise (Cambridge, MIT Press, 1962).

5. K. Andrews, The Concepts of Corporate Strategy (Homewood, Dow Jones Irwin, 1971).

6. M.E. Porter, Competitive Strategy: Techniques for Analyzing Industries and Competitors (New York, Free Press, 1980).

7. B. Wernerfelt, 'A Resource Based View of the Firm', Strategic Management Journal, 5, 1984, pp. $171-180$.

8. J. Barney, 'Firm Resources and Sustained Competitive Advantage', Journal of Management, 17, 1, 1991, pp. 99-120; J. Barney, 'Is the Resource-Based View a Useful Perspective for Strategic Management Research? Yes', Academy of Management Review, 26, 1, 2001, pp. 41-56.

9. H. Chen, L.J. Hexter \& M.J. Hu, 'Management Ownership and Corporate Value', Managerial and Decision Economics, 14, 1993, pp. 335-346; Short, H. (1994): 'Ownership, Control, Financial Structure and the Performance of the Firm', Journal of Economic Surveys, 8, 3, pp. 203-249; C. Galve \& V. Salas, 'Ownership structure and firm performance: Some empirical evidence from Spain', Managerial and Decision Economics, 17, 1996, pp. 575-586; L.E. Reyes, 'La estructura de propiedad y control de las empresas no fiancieras cotizadas: una descripción de la situación actual ante las reformas del gobierno corporativo', Dirección y Organización, 27, 2002, pp. 112-126.

10. M.H. Cho, 'Ownership Structure, Investment and Corporate Value: An Empirical Analysis', fournal of Financial Economic, 47, 1998, pp. 103-123. 


\section{S. Bruque et al.}

11. K. Ramaswamy, 'Organizational Ownership, Competitive Intensity, and Firm Performance: An Empirical Study of the Indian Manufacturing Sector', Strategic Management Fournal, 22, 2001, pp. 989-998.

12. D.O. Côté, 'La eficiencia de la empresa y la estructura de propiedad', Ciriec-España, 10, 1991, pp. $17-40$.

13. A. Vargas, 'Los emprendedores y los valores cooperativos. Consideración del papel de la información en el desarrollo de redes de empresa en democracia', in: J. Moyano (Ed.), La sociedad cooperativa: un análisis de sus características societarias y empresariales (Jaén, Servicio de Publicaciones de la Universidad de Jaén y Caja Rural de Jaén, 2001), pp. 23-38.

14. R. Bowels, 'Property Rights and the Legal System, in: E. Dwhynes (Ed.), GAT is Political Economy (New York, Basil Blackwell, 1984), pp. 187-208.

15. J. Freeman \& A. Lomi, 'Resource Positioning and Foundings of Banking Cooperatives in Italy', in: J.A.C. Baum \& J.V. Singh (Eds), Evolutionary Dynamics of Organizations (New York, Oxford University Press, 1994), pp. 269-263.

16. H. Aldrich \& P.V. Marsden, 'Environments and Organizations', in: N.I. Smelzer (Ed.), Handbook of Sociology (Beverly Hills, Sage, 1988), pp. 361-392; D.N. Barron, E. West \& M.T. Hannan, 'Deregulation and Competition in the Financial Industry', Industrial and Corporate Change, 7, 1998, pp. $1-32$.

17. G. García-Gutiérrez, 'El problema de la doble condición de los socios-trabajadores (sociosproveedores y socios-consumidores) ante la gerencia de la empresa cooperativa', Revesco, 56-57, 1988-1989, pp. 83-121.

18. J.A. Prieto, 'La participación de los socios en los procesos de producción y distribución de la sociedad cooperativa: los socios consumidores de bienes ylo servicios, in: J. Hoyano (Ed.) La Sociedad cooperative: un analisis de fus carocteristicas societancio y empresariales (Jaén Servicio de publicaciones de la Universided de Jaén, 2001), pp. 103-180.

19. E. Locke \& D.M. Schweiger, 'Participation in Decisión-Making: One More Look', in: L.L. Cummings \& B.M. Staw (Eds), Research in Organizational Behavior (Greenwich, 1979), pp. 265-339.

20. D.M. Schweiger \& G.R. Leana, 'Participation in Decision-Making', in: E.A. Locke (Ed.), Generalizing from Laboratory to Field Studies (1986), pp. 147-166.

21. A. Vargas, M.A. Grávalos \& P. Marín, 'Algunas reflexiones acerca de la excelencia cooperativa', in: R.M. Hernández (Ed.), La reconstrucción de la empresa en el nuevo orden económico,(Cáceres, Universidad de Extremadura, 1994), pp. 1.053-1.054; B. Rodrigo, 'La excelencia empresarial en la sociedad cooperativa', CIRIEC-España, 19, 1995, pp. 43-54.

22. D.P. Lepak \& S.A. Snell, 'The Human Resource Architecture: Toward a Theory of Human Capital Allocation and Development', The Academy of Management Review, 24, 1, 1999, pp. 31-48.

23. G.K. Prahalad \& G. Hamel, 'The Core Competences of the Corporation', Harvard Business Reviere, May-June 1990, pp. 79-91; R. Hall, 'A Framework Linking Intangible Resources and Capabilities to Sustainable Competitive Advantage', Strategic Management Journal, 14, 1993, pp. 607-618.

24. M.E. Porter \& V.E. Millar, 'How Information Gives You Competitive Advantage', Harvard Business Review, 64, 4,1985, pp. 149-160; E. Brynjolfsson, L. Hitt \& S. Yang, 'Intangible Assets: How the Interaction of Computers and Organizational Structure Affects Stock Market Valuations', MIT Working Paper, 2000, available at http://ecommerce.mit.edu/erik/index.html, 30 November 2000; A. McAfee, 'The Impact of Enterprise Information Technology Adoption on Operational Performance: An Empirical Investigation', Working paper, Harvard Business School, Boston, 2001; A. Blinder, 'La nueva economía', in: Internet Policy Institute, Informe al presidente de los Estados Unidos sobre Internet (Madrid, Fundación Retevisión, 2001), pp. 33-38.

25. J.W. Ross, G.M. Beath \& D.L. Goodhue, 'Develop Long-Term Competitiveness Through IT Assets', Sloan Management Reviere, Fall, 1996, pp. 31-42; T.H. Davenport, 'Human-centered information management', in: Harvard Business Review, Harvard Business Review on the Business Value of IT (Boston, Harvard Business School Press, 1999), pp. 1-33.

26. C. Powell \& A. Dent-Micallef, 'Information Technology as Competitive Advantage: The Role of Human, Business and Technology Resources', Strategic Management Fournal, 18, 5, 1997, pp. 375-405.

27. A.S. Bharadwaj, 'A Resource-Based Perspective on Information Technology Capability and Firm Performance', MIS Quarterly, 24, 1, 2000, pp. 169-198; Brynjolfsson et al., op. cit., Ref. 24. 
28. ESADE, 'Flashes sectoriales, Industria farmacéutica', available at http://www.guiame.net/flash / farma.html, 12 July 2000.

29. Farmaindustria, La industria farmacéutica en cifras (Madrid, Farmaindustria, 1999).

30. Ibid.

31. F. Martínez, 'Cooperativa de Farmacéuticos de España: Cofares', REVESCO, Revista de Estudios Cooperativos, No. 62, 1996, pp. 127-176.

32. P. Malo, 'Cofares, Una historia de la distribución farmacéutica', Grupo Cofares, Madrid, 1994; A. Erasun Pellon, 'La distribución farmacéutica cooperativa en la asistencia sanitaria', REVESCO, Revista de Estudios Cooperativos, No. 62, 1996, pp. 171-176.

33. C. Ruiz De Gauna, 'Almacén de guardia para 1.500 farmacias', available at http://www. expansiondirecto.com, 11 September 2000.

34. Powell \& Dent-Micallef, op. cit., Ref. 26.

35. U. Sekaran, Research Methods for Business; A Skill Business Approach (New York, Wiley, 2000).

36. L. Cronbach, 'Coefficient Alpha and the Internal Structure of Tests', Psychometrica, 16, 1951, pp. 297-334.

37. A. Van De Ven \& D. Ferry, Measuring and Assessing Organizations (New York, Wiley, 1979); Powell \& Dent-Micallef, op. cit., Ref. 26.

38. J.F. Hair, R.E. Anderson, R.L. Tatham \& W.C. Black, Análisis Multivariante (Madrid, Prentice Hall, 1999).

39. Farmaindustria, op. cit., Ref. 29.

40. Sekaran, op. cit., Ref. 35.

41. L. Gómez-Mejía, 'Structure and Process of Diversification, Compensation Strategy, and Firm Perfomance', Strategic Management Journal, 13, 1992, pp. 381-397; L.L. Martins \& A. Kambil, 'Looking Back and Thinking Ahead: Effects of Prior Success on Managers' Interpretations of New Technologies', Academy of Management Journal, 42, 1999, pp. 652-661.

42. A. Vargas, Las almazaras cooperativas onubenses, una propuesta de actuación ante la crisis (Huelva, Publicaciones del Monte de Piedad y Caja de Ahorros de Córdoba, 1993).

43. Barney (2001), op. cit., Ref. 8 .

44. R. Henderson \& I. Cockburn, 'Measuring Competence?: Exploring Firm Effects in Pharmaceutical Research', Strategic Management Journal, Special Issue, 15, 1994, pp. 63-84; S.K. Majumdar, 'On the Utilization of Resources: Perspectives from the U.S. Telecommunications Industry', Strategic Management Journal, 19, 1998, pp. 809-831

45. Powell \& Dent-Micallef, op. cit., Ref. 26.

46. W.G. Sepherd, 'The Elements of Market Structure', Review of Economics and Statistics, 54, 1, 1972 , pp. 25-37; G.S. Hansen \& B. Wernelfelt, 'Determinants of Firm Performance: The Relative Importance of Economic and Organizational Factors', Strategic Management Journal, 10, 1989, pp. 399-411; Ramaswamy, op. cit., Ref. 11.

47. Powell \& Dent-Micallef, op. cit., Ref. 37.

48. H. Mintzberg, La estructuración de las organizaciones (Barcelona, Ariel, 1984).

49. T.C. Powell, 'Strategic Alignment as Competitive Advantage', Strategic Management fournal, 13, 7, 1992, pp. 551-558; Powell \& Dent-Micallef, op. cit., Ref. 26.

50. J. Lee \& D. Miller, 'People matter: Commitment to employees, strategy and performance in Korean firms', Strategic Management fournal, 20, 1999, pp. 579-593.

51. P. Kotler \& G. Armstrong, Fundamentos de Mercadotecnia (México, Prentice Hall, 1991).

52. Y. Spanos \& S. Lioukas, 'An Examination into the Causal Logic of Rent Generation: Contrasting Porter's Competitive Strategy Framework and the Resource Based Perspective', Strategic Management Journal, 22, 2001, pp. 907-934.

53. M.A. Hitt, L. Bierman, K. Shimizu \& R. Kochhar, 'Direct and Moderating Effect of Human Capital on Strategy and Performance in Profesional Service Firms: A Resource-Based Perspective', Academy of Management fournal, 44, 1, 2001, pp. 13-28.

54. T.C. Powell, 'How Much Does Industry Matter?, An Alternative Empirical Test', Strategic Management Journal, 17, 1996, pp. 323-334.

55. Hansen \& Wernelfelt, op. cit., Ref. 46; Hitt et al., op. cit., Ref. 53; Ramaswamy, op. cit., Ref. 11.

56. Sekaran, op. cit., Ref. 35.

57. Vargas, op cit., Ref. 21; Rodrigo, op cit., Ref. 21. 


\section{S. Bruque et al.}

58. M. Peteraf, 'The cornerstones of competitive advantage: A resource based view', Strategic Management Journal, 14, 1993, pp. 179-191.

59. J. Barney, 'Looking inside for competitve advantage', Academy of Management Executive, 9, 4, 1995, pp. $49-61$.

60. E.K. Clemons \& M.C. Row, 'Sustaining IT advantage: the role of structural differences', Management Information Systems Quarterly, September, 1991, pp. 275-292.

61. R.M. Solow 'We'd better watch out', New York Times Book Review, 12nd July, 1987, p. 36.

\section{Appendix 1: Information Technology Use Measures}

Respondents were asked to indicate the extent to which they are using the information technologies indicated below, using a $0-5$ scale $(5=$ high degree of utilization; $1=$ not yet begun to use the technology; $3=$ medium point; $0=$ do not intend to use)

Communication systems with customers:

1. One-way communication via modem between the pharmacies and the information system of the firm

2. Two-way communication via modem between the pharmacies and the information system of the firm.

Communication systems with suppliers:

3. Electronic transactions with buying-centers via EDI.

4. Electronic transactions with buying-centers via the Internet.

5. Electronic transactions with pharmaceutical suppliers via EDI.

6. Electronic transactions with pharmaceutical suppliers via the Internet.

Internal communication systems or internal networks:

7. Local network that interconnects the computers and the buildings of the firm.

8. Use of e-mail and file transfer.

Internet / Intranet Technologies:

9. URL based website.

10. Intranet with firewall accessible to clients and to other members of the organization.

11. Technical and professional support via the website.

12. e-commerce website to sell non-medical products to final clients.

Robotic and telecommunications technologies for store management:

13. Bar code systems for classifying the items at the supply plant.

14. Weight control systems for rejecting incorrect consignments.

15. Robotic supplying and sorting systems.

16. Loading and transport systems managed via radio frequencies.

Other technologies:

17. Specific management software for the pharmacy. 


\section{Appendix 2}

\begin{tabular}{|c|c|}
\hline \multicolumn{2}{|r|}{ Sampling technical specifications } \\
\hline Population & $\begin{array}{l}\text { Customers of pharmaceutical distribution firms in } 10 \text { provinces in the South and Centre } \\
\text { of Spain }\end{array}$ \\
\hline Population frame & Pharmacies in the above-mentioned geographical area \\
\hline Sample elements & Customers of pharmaceutical distribution firms in the above-mentioned geographical area \\
\hline Geographical scope & $\begin{array}{l}\text { Provinces of Jaen, Cordoba, Sevilla, Huelva, Cadiz; Malaga, Granada, Almeria, Murcia } \\
\text { and Ciudad Real }\end{array}$ \\
\hline Data gathering period & June-September 2000 \\
\hline \multicolumn{2}{|l|}{ Sample } \\
\hline Sampling design & Probabilistic, stratified random disproportionate sampling \\
\hline Sampling error & Between \pm 1.25 and \pm 0.10 in absolute value of mean valuation for each item \\
\hline Sampling size & 623 valuations, generated by 231 different clients \\
\hline Data collection & Mail questionnaires \\
\hline
\end{tabular}


Copyright $\odot 2003$ EBSCO Publishing 